\title{
O Gancho - da mídia impressa às mídias eletrônicas
}

Resumo - O presente trabalho analisa o gancho, recurso narrativo que teve sua origem na literatura oral, com os contadores de história, e que foi apropriado pela indústria cultural, na imprensa, no rádio e na televisão. Acompanha o desenvolvimento dessa estratégia cativar o público e criar um fluxo narrativo estimulando a participação do espectador na trama. Finalmente, o texto discute a utilização desse recurso nas novas mídias digitais.

\section{Introdução}

Helena $^{1}$ entra em casa, vinda do trabalho. Encosta-se à porta depois de fechá-la e corre os olhos pela sala de estar de sua casa, meio na penumbra. Sua expressão é angustiada. Recompõese e começa a percorrer o cômodo em direção à porta que dá para a parte interna da casa. Passeia o olhar por tudo como se procurasse alguma coisa. $\mathrm{O}$ espectador, que acompanha a trama, compreende a ansiedade que a personagem exibe - ela suspeita que a filha, Camila, mal saída da adolescência, esteja se apaixonando pelo seu namorado, Edu, armando-se um obstáculo insuperável para o romance que ela vem vivendo na novela. Helena dirige-se para o quarto, aparentemente, em busca de descanso ou consolo, mas antes de se acomodar vê a porta fechada do quarto de Camila. Sente-se atraída por aquele cômodo como se quisesse penetrar a intimidade da filha. Ela abre a porta e penetra no dormitório. Seu olhar fixa uma fotografia na qual aparecem sorridentes e despreocupados a menina, Edu e ela, num trágico triângulo amoroso pressentido pela máquina fotográfica. $\mathrm{O}$ contraste entre a alegria evidente na foto e a tensão vivida pelas personagens é recurso clássico das narrativas melodramáticas. Toda essa emoção é acompanhada por uma música romântica de fundo e pela câmera que se fecha em close, lentamente, no rosto ansioso de Helena que, assim, expõe ao público toda sua dor e angústia. Ouve-se a trilha sonora de abertura e os letreiros varrem a tela. $\mathrm{O}$ capítulo termina deixando no ar toda a ansiedade e a dúvida da protagonista sugeridas por sua expressão, pela lentidão com que a câmera capta essa seqüência, pela penumbra do ambiente e pela música de fundo cheia de alusões. O espectador, certamente, permanece ainda um bom tempo imerso na sensação conflitante despertada pela situação de Helena. Pouco a pouco ele se recompõe e passa para outro programa, outro estado de espírito, outro contexto. Mas, lá no fundo, as perguntas não respondidas ficam remoendo em sua memória e em seu imaginário. Como Helena reagirá à certeza do envolvimento da filha com o namorado? E Edu, deixará a namorada, envolvendo-se com a filha, Camila? Como se enfrenta esse triângulo amoroso cujo conflito milenar inspira os autores das mais variadas linguagens, escolas e culturas, há milhares de gerações?

As perguntas que ficaram pendentes, os conflitos que se anunciam, as emoções que se contrapõem, resşoam no imaginário do ouvinte/ espectador, trazendo-lhe imagens arcaicas carregadas de afetividade. Essa ressonância ${ }^{2}$ permanece no ar estimulada por uma história que foi 
interrompida no seu ponto de maior tensão, quando toda a carga afetiva da personagem se encontra mobilizada, exposta e ao alcance do público. Ela flutua sob a forma de imagens feitas de sons, de cores e de movimentos, imagens que assombram o público ansioso pela resposta, solução, ou desenlace. É o gancho que encerra o capítulo das narrativas seriadas e prepara já o próximo encontro, quando a história será retomada exatamente no momento da sua ruptura, a partir da cena de corte.

No dia seguinte, a história recomeçará de onde parou - Helena olhará demoradamente para a foto que enfeita o quarto da filha e talvez saia de mansinho para esconder-se em seu próprio quarto ou pode ser que, num momento de raiva, rasgue a fotografia que previra, com tanta sutileza, a relação dramática entre os três personagens. Ou o que mais será possível? Com essas perguntas sem respostas, mas cheias de sugestão e de prenúncios de emoções envolventes, o espectador aguardará ansioso pelo dia seguinte. Sua curiosidade estimulada, suas emoções despertadas, seus desejos acordados, permitirão que, mesmo em meio às lides cotidianas, ele se entretenha com o enredo contínuo e permanente das narrativas seriadas.

\section{As origens seculares do gancho}

O recurso do gancho é utilizado há milênios pelos bons narradores de histórias e, mesmo quando estas eram apenas contadas à viva voz, diante de platéias que escutavam atentas, o ritmo narrativo permitia o uso de alentamentos estratégicos que estimulavam o imaginário dos ouvintes. A suspensão do enredo nos momentos mais tensos quando o desfecho de conflitos, o choque de personagens ou perigos iminentes estavam por acontecer, tornavam famosos os contadores que sabiam usá-la de forma adequada.

Manguei, no livro $A$ História da Leitura, fala dos serões domésticos de leitura em voz alta, quando as mulheres, estimuladas pelos enredos, mas ainda afastadas da escola, aprendiam a ler e a escrever. Nessas oportunidades, o suspense premeditado da história era usado como elemento de envolvimento e sedução. Os grandes leitores de narrativas, conta Manguei, sempre souberam que manter o interesse de seu ouvinte era parte da certeza do prazer da leitura e do sucesso do texto. Sobre Tam Fleck, famoso pelas leituras que fazia de seus livros de aventura, diz o autor: tinha por norma não ler mais de duas ou três páginas de cada vez, entremeadas com observações sagazes, como se fossem notas de pé de página, e dessa forma sustentava um interesse extraordinário pela narrativa ${ }^{3}$. Seu saber havia aprendido com uma velha parenta que contava histórias para ele e para seu irmão.

Pregadores de diferentes doutrinas, em seu esforço de conversão, não hesitavam em lançar mão de recursos narrativos próprios da cultura popular. Sacerdotes cristãos aproveitavam-se de provérbios, ditos populares, aforismos e também dos ganchos. Os sermões nos quais utilizavam técnicas consagradas da oralidade eram interrompidos em momentos de tensão para que o público acompanhasse atento as peripécias do Antigo e Novo Testamentos. Após demoradas pausas sugestivas, os sacerdotes encerravam os sermões com frases contundentes e reforçadas pelo suspense.

Os meios de comunicação de massa a e a indústria cultural foram muito sensíveis à tradição milenar das formas narrativas, especialmente as populares, daí o uso da comicidade, das expressões mímicas e orais e de estratégias de comunicação, entre as quais está o gancho. Foi ele também que consagrou Sheherazade - personagem das Mil e uma noites e talvez a mais famosa contadora de história de todos os tempos. Diz a lenda que o sultão Schariar, tendo sido traído pela mulher, resolvera mandar executar todas as esposas que tivesse dali para a frente, na noite seguinte às núpcias. Pretendia, assim, evitar novas possíveis traições. Diante da desgraça que então se abateu sobre o reino, Sheherazade decidiu oferecer-se como esposa, driblando a obstinação do marido com a estratégia
(3) MANGU日, Alberto - Uma história da leitura - São Paulo, Ca das Letras, 1997, p. 143. 
de, ao clarear do dia, interromper suas histórias num momento de grande interesse. Curioso pelo final da história, Schariar foi adiando por mil e uma noites a execução da esposa, quando enfim convenceu-se de sua fidelidade, comprovada pela assiduidade com que ela comparecera ao ritual narrativo. ${ }^{4}$

A atenção permanentemente despertada pelos cortes meticulosamente arquitetados seduziam o soberano e o prendiam inelutavelmente à Sheherazade e às suas histórias. A imprensa, o rádio e a televisão souberam, como ela, estabelecer vínculos de fidelidade com o seu público, constantemente interessado no desdobramento das histórias e no desenrolar dos acontecimentos.

O gancho - essa ferramenta com a qual o narrador seciona sua história em pedaços, mantendo o interesse e avivando a curiosidade de seu interlocutor - é uma intrincada gramática que exige todo um "amarramento" próprio da trama. Os ganchos sintetizam os capítulos diários de uma narrativa seriada, demonstrando que as intrigas foram urdidas exatamente para terminarem nesse hiato preciso e calculado - é como se o narrador começasse a escrever o capítulo, pensando já em como encerrá-lo. Podemos dizer que quem escreve tanto conta como sugere o que não conta, quando silencia, corta ou interrompe. Há um enredo que se apresenta no texto e outro que se esconde na imaginação do público, proposto pelo narrador. O gancho acentua os silêncios, as propostas, as ambigüidades, as sugestões, estimula os desejos, as expectativas, os sonhos.

\section{O gancho na mídia}

O gancho tornou-se elemento dos mais importantes na indústria cultural e nas narrativas seriadas nos mais diferentes meios de comunicação ${ }^{5}$. Desde os folhetins que passaram a ser editados diariamente nos jornais que circulavam nas cidades européias no século XIX, utilizavam de maneira adequada o gancho, como meio para manter a atenção de seu leitor, garan- tindo a compra do exemplar do dia seguinte quando os desenlaces das histórias seriam enfim conhecidos. O autor, sabiamente, conseguia satisfazer a curiosidade desse leitor e criar novos interesses e amarrações cuja solução ele deixaria sempre para outro dia. A narrativa seriada e o bom uso do gancho foram responsáveis, entre outros fatores, pelo hábito que se formou de leitura diária desses periódicos.

Marlyse Meyer identifica o gancho como uma das características da literatura folhetinesca e afirma que a exigência desse recurso passou a influenciar a própria estrutura do romance e a caracterizar o estilo dos autores, tornando alguns deles famosos pela perícia que demonstravam ao usá-

lo. Balzac, segundo Meyer, teria sido um admirador de Eugène Sue e teria com ele aprendido a fragmentar seus romances. A arte do gancho implica em cortar de forma adequada a história em capítulos sem destruir a impressão de continuidade e totalidade . $^{\text {. }}$

A indústria cultural foi se especializando nesse mister e quando, além da imprensa, passou a contar com outras mídias como o rádio e a televisão, cuja oralidade as aproxima das narrativas populares, o uso desses mecanismos de sedução e de mobilização psico-social se tomou cada vez mais imperioso. Com uma grade horária ininterrupta e com a audiência doméstica, os novos meios de comunicação passaram a levar cada vez mais a sério sua capacidade de disputar a atenção do público tornandoo também fiel aos seus encontros narrativos. Assim, a relação que se estabelece é mais estreita e envolvente. $\mathrm{O}$ gancho, aguçando a imaginação e a curiosidade de ouvintes e telespectadores, passa a ser um recurso dos mais utilizados.

Desde o início da programação radiofônica e televisiva, as narrativas seriadas exibiram o talento no uso do corte, deixando o público "pendurado" nas emoções diárias, dosadas e em conta-gotas. Embora o termo gancho tenha nascido da prática jornalística, referindo-se à relação possível estabelecida entre matérias diferentes, 
ele se consagra como elemento característico das narrativas essencialmente ficcionais. Tendo por característica a linguagem poética e o uso de metáforas, a obra de ficção exige o mergulho do leitor/ouvinte, ou do receptor, na trama criada. O gancho é uma das alavancas desse complexo processo ficcional. A esse respeito nos diz Umberto Eco: Em toda obra de ficção, o texto emite sinais de suspense, quase como se o discurso se tornasse mais lento ou até parasse, e como se o escritor estivesse sugerindo: "agora tente você continuar... " 7

Por mais de um século, as histórias aos pedaços ajudaram a promover uma revolução silenciosa nas sociedades modernas - incentivaram a alfabetização, criaram o hábito de leitura diário e estimularam o público a substituir a experiência imediata por uma vivência mediada pela indústria, mas compartilhada pela coletividade. Desde o século XIX, quando surgiram, até meados do XX, a cultura se tornou repleta dessas histórias cuja trama faz avançar, regularmente, semana a semana, mês a mês, dia a dia, uma história cheia de ações e emoções, aprimorando-se essa técnica de secionar e emendar capítulos. O desenvolvimento tecnológico foi diversificando os formatos nos quais esses enredos se desenrolavam, surgindo fotonovelas, radionovelas, o cinema seriado e as telenovelas, mantendo-se, entretanto, as mesmas características do gênero infindáveis melodramas de cunho moralista que renovavam a eterna disputa entre o bem e o mal. Oferecidas de forma seriada, essas histórias tornaram-se notáveis no uso e abuso de ganchos, estimulado também pelas mensagens comerciais que passaram a ser veiculadas nos intervalos entre blocos e capítulos. A serialidade, segundo Jesús Martin Barbero, acomodava os princípios da produção industrial aos hábitos do consumo, instituindo as bases da cultura massiva. Los géneros, que articulan narrativamente las serialidades constituyen una mediación fundamental entre las lógicas del sistema productivo y del sistema de consumo, entre la del formato y de los modos de leer de los usos, diz ele 8 .

A cada nova mídia que se desenvolvia e incorporava essa forma de contar histórias, a arte de cortar e emendar, própria do gancho, assumia características diferentes que excediam a simples modulação formal de uma narrativa - de uma lado, havia a acirrada disputa entre meios e canais existentes que batalhavam pela atenção do público e, de outro, enfrentavam-se problemas técnicos cuja crescente complexidade tramava contra o desejável fluxo narrativo dos programas.

Mario Fanucchi, radialista e profissional da televisão brasileira desde seus primórdios, conta em seu livro Nossa próxima atração ${ }^{9}$ a dificuldade experimentada pelos profissionais da TV na tentativa de reduzir os intervalos da programação. Com poucos recursos técnicos e muita improvisação, buscava-se amarrar as diversas cenas de um mesmo programa e os diversos programas num conjunto harmonioso e interessante para o espectador, tomando o menos perceptível possível a escassez de profissionais e de cenários que transformavam numa pequena batalha cada intervalo. As demoras eram mal recebidas e mal suportadas pelo público, obrigando a produção a uma verdadeira corrida contra o tempo. Assim, ganhavam importância os interprogramas utilizados para a publicidade, para anúncio da programação subseqüente e até para experiências gráficas e em texto corrido - ousadias impensáveis nos tempos atuais. A arte do gancho adquiria independência, libertava-se do texto e intrometia-se nas questões de produção. Por outro lado, já se apresentavam as questões de ritmo, fluxo narrativo e rapidez na transmissão como elementos próprios das comunicações midiáticas.

Foi em razão desse cenário propício ao desenvolvimento da cultura de massa e ao sucesso comercial das programações televisivas que o gancho foi se modificando e foi tendo uma participação cada vez mais ampla e
(7) ECO, Umberto - Seis passeios pelos bosques da ficção - São Paulo, Cia das Letras, 1994, p. 56. (8) MARTÍN-BARBERO, Jesús-De los medios a las mediaciones Barcelona, Editorial Gustavo Gili, 1987, p. 239.

(9) FANUCCI, Mario-Nossa Próxima atração -SãoPaulo, EUSP, 1996. 
diferenciada no discurso massivo. Nas palavras de Fanucchi, o intervalo transcendia o papel de mero complemento da programação e atingia quase o status de programa ${ }^{10}$.

Mas o que já podemos notar, nesta etapa de apropriação de recursos narrativos provenientes da tradição oral e da cultura popular pela indústria cultural, é que ela implica numa mudança de função do elemento apropriado e num deslocamento de sua inserção no processo produtivo. $\mathrm{O}$ gancho na comunicação oral era essencialmente um recurso narrativo do autor, uma competência de quem detinha o poder sobre a história em retardar seu desfecho, explorando a curiosidade e o interesse do ouvinte e, conseqüentemente, obtendo maior envolvimento deste no processo comunicativo. Ao migrar da tradição oral para a imprensa e, mais tarde, para o rádio e a televisão, o gancho passa a ser uma ferramenta não só do autor propriamente dito, mas de toda a cadeia produtiva que envolve a criação cultural em moldes industriais. Essa habilidade do narrador de manter o público mergulhado numa narrativa passou a ser requerida também dos diretores, produtores e apresentadores, cada um tentando fazer desaparecer do fluxo narrativo os intervalos impostos à comunicação não mais pela urgência da vida cotidiana, mas pelas necessidades de um processo comunicativo que se sofisticava, se mercantilizava e se fragmentava.

Além disso, o gancho deixa de ser um recurso narrativo do bom orador e do bom contador de histórias para se transformar numa tática que encobre as características e fragilidades da comunicação midiática. Ele participa assim dessa naturalização dos meios de comunicação de massa a partir da qual todo ruído provocado pelas características da nova linguagem e pelo processo produtivo de que resulta, assim como a estranheza que possa provocar inicialmente no público, é disfarçado pela adoção de recursos conhecidos, familiares e populares.

Sugestivo dessa tendência é o que nos conta Mario Fanucchi a respeito da logomarca criada para a TV Tupi Difusora, Canal 3, primeira emissora de televisão a transmitir programas regulares no Brasil. Antes do início da programação diária que só começava às 20 horas, aparecia na tela, para ajuste da imagem, um diagrama com círculos e coordenadas no qual se via a cabeça de um índio norte-americano. Dados os atrasos constantes do início da transmissão, essa imagem ficou desgastada, tomando-se sinônimo de indesejável dęmora - um verdadeiro "programa de índio". Sem ferir o "indigenismo" da empresa e buscando melhorar a empatia dessa abertura junto ao público, foi criada a famosa figura do indiozinho "Tupiniquim"- mais jovem e com uma cara alegre11 - um curumim que utilizava uma antena de televisor no lugar do cocar. Associado à legenda "Nossa Próxima Atração", esse interprograma estimulava interesse e tolerância junto aos espectadores, tomando-se uma das mais antigas e conhecidas personagens televisivas. Assim funciona o processo de camuflagem, de naturalização e familiaridade do processo midiático, uma das raízes de sua espetacularização - a substituição da realidade por imagens que a contradizem e ludibriam ${ }^{12}$.

A invenção do videotape, na década de sessenta, minimizou os problemas com a constante improvisação a que se sujeitavam os profissionais da TV - troca de cenários, de elenco e de programa - mas fez aumentar a descontinuidade da linguagem televisiva com o uso cada vez mais intenso da edição do material previamente gravado. A arte do "corte e costura", das chamadas e da comunicação envolvente, capaz de se prolongar na memória do espectador, consagrava-se, mas produzia uma narrativa cada vez mais descontínua.

Por outro lado, o alto preço alcançado pelas emissoras na venda dos espaços publicitários levou a uma aceleração da linguagem televisiva com mensagens que procuravam falar cada vez mais em menos tempo, através de um estilo quase metonímico e minimalista. Essa aceleração impregnou 
a programação regular e, em especial, as telenovelas, caracterizadas até então por uma narrativa lenta, repetitiva e cotidiana. $\mathrm{O}$ resultado foi o uso de uma maior quantidade de câmeras filmando vários ângulos diferentes, e um maior número de cortes. Se nas novelas brasileiras da década de sessenta havia cenas de até cinco minutos de duração, atualmente elas raramente ultrapassam um minuto, parecendo, mesmo assim, longas ao espectador. Cortar e emendar tornou-se tarefa importante de autores, diretores e editores de narrativas televisivas, todos eles buscando não cansar os espectadores e, ao mesmo tempo, despertar-lhes o interesse é uma fidelidade de sultão apaixonado.

Mas, não param aí as preocupações crescentes com a atenção e fidelidade do espectador - o controle remoto, ampliando junto ao público a possibilidade de troca de canais, e o surgimento de novas emissoras que ameaçam a posição hegemônica das emissoras mais consagradas, levam essa Sheherazade eletrônica a uma atitude ansiosa de verdadeira perseguição por sua assistência - os folhetins tornaram-se mais melodramáticos e o gancho, cada vez mais elaborado. O que estamos chamando de "ganchos mais elaborados"? Em telenovelas, os ganchos são mais refinados quando toma-se explícita a escolha da cena que encerra o capitulo, envolvendo, quando possível, o conflito central da história; quando os protagonistas aparecem no momento do corte; quando a direção de câmera acentua a expressão fisionômica do ator e o close faz com que o espectador mergulhe no interior da personagem e, finalmente, quando a última fala parece dirigir-se diretamente ao público, despedindo-se dele.

A aceleração da linguagem televisiva e essa preocupação com o corte e a continuidade da narrativa ficam evidentes nas telenovelas atuais quando, após a repetição da cena de corte do dia anterior, prossegue-se com o capítulo sem colocar no ar a ficha técnica, como era usual até pouco tempo atrás. Não há um minuto a perder nesse processo intrincado e cada vez mais instável de sedução. $\mathrm{O}$ gancho tradicional que mostrava as "cenas dos próximos capítulos" também foi suprimido em favor de uma curiosidade mais sutil e eficaz.

Nos demais intervalos da programação, o gancho se mostra mais sofisticado quando aberturas e vinhetas são elaboradas com maior apuro e quando as chamadas se multiplicam na transmissão diária. A produção de making-off e a criação de expectativas junto ao público podem ser consideradas como verdadeiros ganchos paralelos. Nota-se até a tendência para que artistas de uma determinada programação sejam foco de notícias que reiterem sua atuação televisiva.

Além do advento do controle remoto, arma indispensável do público televisivo, os anos noventa assistiram a instalação das TVs a cabo, acirrando a competição entre programas televisivos nacionais e estrangeiros. $\mathrm{O}$ desenvolvimento tecnológico, as transformações do meio, a excessiva comercialização dos espaços e a concorrência fizeram da linguagem midiática um tecido cada vez mais fragmentado em que as pausas e os apelos se tomaram imperativos.

Os noticiários, constantemente interrompidos pela publicidade, começaram também a fazer uso do gancho, não mais como uma ligação entre assuntos diversos ou como intervalos publicitários, mas como elemento capaz de trazer o ouvinte de volta, depois de passar pelos inconvenientes mas necessários anúncios. Introduzir as manchetes das notícias que estão previstas para os blocos subseqüentes, estimulando curiosidades e interesses, tornou-se um recurso cada vez mais comum nos diversos veículos da mídia. Como os pregões dos vendedores ambulantes, o anúncio daquilo que será apresentado alcança o público, desperta apetites e chama a atenção.

Não é raro que figuras de impacto apareçam na televisão, pouco antes dos intervalos, convidando o público a retornar à programação, seduzindo-o com o anúncio do que o 
espera após os comerciais. Abre-se um sorriso e o artista ou âncora termina sua fala com um inevitável: "você não pode perder..."

Também o formato dos programas de entrevistas e variedades tem procurado privilegiar essa amarração e esse apelo ao público entre os blocos separados por comerciais: No Fantástico, programa de variedades exibido nas noites de Domingo, pela Rede Globo, há décadas, foi criada uma nova estratégia que remete aos recursos do gancho. No penúltimo bloco, os apresentadores perguntam ao público qual o assunto que desejam ver tratado nas matérias a serem produzidas para a próxima semana. Três temas são propostos e os telespectadores são convidados a escolher através de ligações telefônicas. Ao final da noite, informa-se o tema escolhido, criandose a expectativa em relação ao próximo programa - trata-se de um gancho entre blocos e entre programas. Assim, o gancho se expande e se transforma em elemento característico da linguagem televisiva, mostrando, por um lado, o alargamento desse mercado e a proliferação de opções e, por outro, a importância dada ao receptor que aparece, para a indústria cultural, como o poderoso sultão que manteve Sheherazade entre a vida e a morte por quase mil e uma noites. Com isso, os recursos de corte, seriação, fragmentação e fidelidade na relação comunicativa tornam-se cada vez mais complexos e elaborados.

O programa Você Decide, também da Rede Globo, estimula o interesse do espectador possibilitando a sua intervenção no desenlace do conflito abordado pela história - através de uma chamada telefônica ele opta por um entre dois finais que a emissora lhe indica. Além desse recurso que incentiva a participação do público, o papel sedutor do apresentador leva quem assiste ao programa a responder de maneira positiva ao seu "Você verá no próximo bloco...", convite irrecusável quando feito por artistas de grande popularidade como o ator Tony Ramos ou o ex-modelo Luciano Szaffir (pai da filha da apresentadora Xuxa).

Há na televisão brasileira um novo formato que mistura ficção e realidade - é o No Limite, produzido também pela Rede Globo, inspirado no popularíssimo Big Brother, já apresentado na Europa e nos Estados Unidos. Os participantes são geralmente jovens e não atores que, selecionados pela emissora, prestam-se a uma experiência nova: conviver durante certo tempo em um espaço determinado e sem contato com pessoas externas à produção, enfrentando desafios como falta de comida, cansaço e conflitos de relacionamento entre os participantes. Todo esse processo é gravado pela emissora que exibe, semanalmente, trechos dessa vivência. Ao final do capítulo apresentado, os participantes votam pela exclusão de um dentre eles. Aquele que permanecer, vencendo as provas e resistindo ao processo de exclusão, ganha um prêmio em dinheiro. A decisão final depende também de votos dos espectadores.

Trata-se de um formato que mescla ficção, realidade, brincadeira e gincana e que trabalha com a expectativa de desempenho dos jovens e com a difícil experiência da expulsão do grupo. Há nesse programa a nítida preocupação com os elementos de mobilização psico-social: a participação de pessoas "comuns" que acentuam o naturalismo televisivo, o apelo voyeurista do público que assiste à vida íntima e cotidiana do grupo, além do gancho que se caracteriza pela surpresa em relação a quem será eliminado a cada semana. A possibilidade de participação do público na escolha do vencedor, nos moldes do Você Decide - também é fator de mobilização.

Mas, poderemos continuar chamando esses recursos televisivos de ganchos ou será que as transformações aqui mencionadas os descaracterizam? Para efeito das nossas análises e da forma como concebemos essa técnica de elaboração narrativa, continuam sendo ganchos: constituem-se em estratégias de interrupção/costura de uma história com o objetivo explícito de despertar o interesse, a curiosidade e a 
atenção do espectador/ouvinte para seu desfecho. Continuam sendo ganchos por serem recursos através dos quais uma programação resolve a descontinuidade imposta pela grade de programação, por comerciais ou pela excessiva pré-produção dos programas.

Porém, como em toda linguagem que se desenvolve, o gancho sofreu um processo de complexificação que fez dele mais do que o resultado da habilidade do autor no corte, transformando-se em intrincada forma de mobilização do público, envolvendo outras artimanhas como a ilusão participativa do espectador. Faz parte da cultura da atualidade esse apelo constante à participação nas mais diferentes manifestações - até mesmo no campo das artes plásticas, obras antes intocáveis tornam-se manipuláveis, usáveis e tácteis. Cinema e televisão apresentam-se sob forma interativa e nunca houve tanto empenho, por parte das emissoras em conhecer e ouvir clientes, leitores e interlocutores. Natural, portanto, que a interatividade e a participação se incorporem às estratégias de "fidelização" do público utilizadas pela mídia.

Além das características comuns aos ganchos - esmero no corte e agilidade na costura, há aspectos dessas narrativas que aproximam os ganchos folhetinescos do século XIX da complexa estrutura dos atuais programas televisivos em que os recursos de fragmentação e emenda de textos se sofisticaram. Trata-se das características dessas histórias radionovelas, telenovelas e programas participativos e interativos, do tipo Você Decide e No Limite, têm em comum uma estrutura repetitiva e redundante que permite ao público antever aquilo que o aguarda, além de um estilo emocional que aproxima o sensacionalismo do melodrama.

Como dissemos no início deste texto, a interrupção do capítulo da telenovela faz com que o espectador permaneça conectado à história elaborando o desfecho, torcendo pelo herói e pela solução do conflito. Fosse esse desenlace surpreendente ou inesperado, o gancho não teria esse poder de mobilizar o espectador, remetendo-o para o final da trama. Nesse sentido o gancho se afasta do suspense que, ao contrário, se apoia no mistério e no desfecho que o autor guarda consigo e, muitas vezes, esconde de seu público.

Embora o suspense tenha sido utilizado em inúmeros ganchos de telenovelas, como em Vale Tudo, em que o autor Gilberto Braga manteve os espectadores na dúvida acerca do assassinato de Odete Roithman ${ }^{13}$, eles não se confundem. O suspense é um gênero literário e midiático que diz respeito à obra como um todo e à intensificação de uma situação de medo, mistério ou angústia proposta pela trama. O gancho é um recurso mais formal do que temático (embora seja intensificado por determinados conteúdos temáticos) que diz respeito mais à forma como um narrador conduz sua história. Podemos dizer que o gancho é marcado pela ruptura, pelo secionamento e pelo impedimento da continuidade, enquanto o suspense se manifesta pela intensidade e pela continuidade narrativa. $\mathrm{O}$ próprio Hitchcock afirmou que não se deve confundir suspense com surpresa ${ }^{14}$. Também não podemos confundir ruptura com continuidade.

O gancho, portanto, enquanto estratégia narrativa, vincula-se à repetitividade e a um texto que, ainda que aos pedaços, tem prosseguimento, relacionando-se, assim, explicitamente com a serialidade e com a fidelidade dos interlocutores no processo narrativo. Para obter eficácia nessa empreitada, utiliza-se a surpresa, o suspense, estímulos psico-sensoriais e o apelo participativo do público.

Nova revolução no mundo midiático ocorreu no final do século $\mathrm{XX}$, alterando as tendências que aqui vimos analisando e que configuraram a cultura da Modernidade- o sucesso da informática e a consagração dos meios digitais na comunicação humana. A introdução dos computadores abalou o que até então se fazia no campo da expressão, da comunicação, registro, armazenagem e transmissão de
(13) Vale Tudo foia telenovela apresentada pela Rede Globo de Televisão, no horário das 20 hs, entre 1988 e 1989.

(14) MATUCK, Carlos - Hitchcock Truffaut - Entrevistas - São Paulo, Brasiliense, 1986. 
informações, representando o advento da comunicação em rede, em âmbito globalizado e em linguagem multimidiática. Em pouco mais de duas décadas, viu-se o mundo informatizarse, conectar-se e digitalizar-se, sem que se tenha ainda claros os contornos da chamada sociedade da informação. De uma coisa, entretanto, estamos certos: a comunicação analógica será substituída pela digital e as grandes empresas de comunicação tenderão a ser dominantes, integrando os diversos veículos - imprensa, rádio, televisão e demais mídias eletrônicas. A velocidade com a qual os computadores invadem áreas privilegiadas da sociedade como os sistemas financeiros e a produção de bens, por isso mesmo chamadas de pós-industrial, nos autoriza a dizer que a tecnologia digital ditará as regras dessa sociedade pós-moderna que emerge. Por essa razão, os estudos da comunicação se voltam para as redes de computadores buscando entender parte desse processo de assimilação das mídias tradicionais e de toda a cultura massiva por elas gerada. $\mathrm{Na}$ próxima parte desse trabalho vamos tratar de como esse recurso narrativo, o gancho, tem se incorporado à linguagem digital.

\section{O Gancho em meios digitais}

Falar em meios digitais exige que se enfrente um grande número de dificuldades que vão da novidade e instabilidade dessa mídia até a multiplicidade que apresenta em termos de suportes, formatos e gêneros. Entretanto, mesmo correndo o risco de falar sobre um cenário que poderá estar obsoleto em curto espaço de tempo e de fazer generalizações por demais amplas, podemos afirmar que certas características da linguagem digital começam a ser reconhecidas: estrutura narrativa não linear; fragmentação textual em múltiplas partes componentes; flexibilidade na conexão entre essas partes; estímulo à interatividade com o usuário ou entre usuários; circularidade da informação; predominância do audiovisual e comunicação globalizada.

A rede mundial de teleco- municações instalada nos diversos lugares do mundo tende a integrar as formas tradicionais de comunicação e as diversas mídias, obrigando-as a um processo que transforma suas informações em dados armazenáveis, processáveis, programáveis e acessíveis aos computadores e usuários a ela conectados. Algumas conseqüências desse processo são perceptíveis: transformam-se as formas de representação do mundo que abandonam a semelhança aparente como forma de identidade, um estoque ilimitado de informações se torna disponível, parte das funções cotidianas de pessoas e máquinas se tornam automatizadas. Desterritorialização, invasão da vida privada, substituição da mão-de-obra humana pela máquina são outras repercussões visíveis da informatização.

Focalizando, entretanto, a revolução tecnológica e o desenvolvimento da sociedade midiática, pano de fundo deste ensaio, percebemos a formação de grandes conglomerados midiáticos que integram antigas e novas tecnologias de comunicação, linguagens consagradas e novas gramáticas, gêneros e formatos em transformação. Nesse universo poliforme e polifônico procuramos analisar aspectos que dizem respeito às formas narrativas e ao uso do gancho como a arte milenar do corte e costura de enredos - a serialidade, o fluxo narrativo e a relação com o ouvinte/ espectador/usuário. Sobre isso falaremos agora.

Nessa primeira década em que foi possível observar a criação mais ou menos regular de narrativas digitais, podemos constatar que os meios eletrônicos acentuam a tendência, já verificada nos meios televisivos, à fragmentação dos conteúdos em unidades menores. As dificuldades de leitura dos textos escritos, apresentados em telas verticais iluminadas por luz emitida, e a exigência de grande capacidade de memória para a armazenagem e divulgação de imagens e sons, criam uma preocupação constante com a economia de informações, gerando o que poderíamos chamar de frugalidade 
expressiva. A ânsia pela economia de espaço e memória e pela rapidez de processamento deixariam os publicitários mais ágeis envergonhados com desperdício realizado em outras mídias. Disso resulta uma produção de textos frugais, rápidos e completos em si mesmos, cujas partes não se juntam propriamente, mas antes se justapõem de acordo com a vontade do usuário que os vai acessando na medida de sua curiosidade, interesse, facilidade técnica e disponibilidade de tempo.

Assim, as narrativas em mídias eletrônicas são mais fragmentadas, abertas e flexíveis, permitindo ao usuário não apenas zapear, como na TV, mas navegar, optando, a seu bel prazer, pelas saídas e entradas disponíveis. Há portanto, um número inusitado de cortes que vão sendo costurados de forma aleatória à medida que são acessados os chamados links. Esses links são ferramentas hipertextuais que indexam diferentes textos, interligandoos através de elementos que lhe são comuns. $\mathrm{O}$ movimento que o navegador realiza através dos links pode tanto leválo cada vez mais para o interior do texto, aprofundando-o no processo comunicativo ou no detalhamento da pesquisa, como pode orientá-lo para fora desse conteúdo em direção a outros textos similares. Nesse caso ele pode percorrer os chamados anéis - rings sites publicados na Internet integrados por um objetivo ou assunto comum. Nesse movimento para fora ou por entre textos, o usuário pode instalar-se em grupos de discussão ou integrar-se a comunidades virtuais unidas por interesse comum - jogos, campanhas ou mera sociabilidade. Disso se conclui que a leitura que os meios digitais permitem amplia a tendência à abertura e à fragmentação do fluxo narrativo, já observada em outras mídias, bem como a uma crescente participação do receptor nesse processo ${ }^{15}$.

Estaria Sheherazade preparada para uma situação como essa em que o sultão goza de liberdade para escolher entre suas mil histórias e, talvez até, entre mil contadores igualmente interessados em chamar sua atenção? Para não ser condenada à morte, nossa contadora teria que se valer de mil artimanhas como a sedução do audiovisual, uma interatividade ágil e fácil, uma recepção de natureza imersiva e uma história de conteúdo envolvente capaz de manter seu sultão cada vez mais interessado no seu desenrolar. A interrupção da história exigiria cada vez mais perspicácia, domínio técnico e narrativo.

Além dessa estrutura flexível e circular, colabora para essa comunicação instável, a ausência de uma grade horária e a fraca serialidade dos meios eletrônicos. Ao contrário do rádio e da televisão, as mídias digitais estabelecem uma relação mais livre, ocasional e informal com o público. As informações se superpõem em camadas, não se sucedem como nos meios convencionais, sendo sempre possível voltar no tempo e acessar ou rever o que já passou. A facilidade de registro e gravação dá ao usuário grande liberdade no gerenciamento do horário e da duração da comunicação. Diante disso, a arte de contar histórias tem que ser revista e adaptada. Como garantir o interesse pelo desfecho de uma narrativa ou por determinada solução para um conflito, se cada leitura é única, pessoal e intransferível? Como estabelecer vínculos e medir fidelidades se o ouvinte/usuário pode chegar a qualquer hora e momento?

Não estamos nos referindo apenas às histórias escritas em capítulos que são publicadas na rede e que utilizam os ganchos convencionais dos folhetins, estamos nos referindo aos ganchos próprios da linguagem e do meio computacional - ao esforço por secionar conteúdos mantendo ainda, como dizia Marlyse Meyer, certa continuidade e inteireza. São ganchos que utilizam recursos tecnológicos sofisticados, próprios das novas mídias eletrônicas.

Encontram-se exemplos convencionais de histórias em linguagem literária, cujos capítulos são interrompidos em trechos de maior tensão, abrindo-se a possibilidade do usuário completar a trama com novas peripécias. Ao lado de certas iniciativas
(15) Há pequenas diferencasna navegação eletrônica se estivermos analisando sites conedados à rede Internet ou publicadosem CDs, por exemplo-Os primeiros implicam na comunicabilidade em redee numa intertextualidade mais efetiva. Os CDs apresentam links como costura entre textos e como possibilidade de navegação, mas possuem uma estrutura fechada emsimesma. Não estamos considerando essa diferença no presente texto porquejáhá CDs que podem ser acoplados às redes mundiais de computadores, anulando essa diferença. 
bastante amadoras, encontram-se experiências mais consolidadas de autores consagrados que escrevem romances em capítulos diários publicados na Internet. O uso convencional do gancho, entretanto, perde sua força diante da disponibilidade dos capítulos anteriores na rede e da ausência de uma rotina semanal ou diária de leitura unindo o usuário e o portal literário, ou seja, unindo Sheherazade e o sultão. Inseridas no tempo sem começo e sem fim das redes globalizadas, essas histórias perderam sua continuidade e a inserção no cotidiano do leitor.

Há exemplos, entretanto, que já exibem certa sofisticação autoral, tanto técnica como literária, reinventando a arte do gancho. No endereço http:// www.novela web.com.br/port.novelas/ 1st/cap1 publica-se uma novela que tenta adaptar o formato televisivo para a Internet, utilizando vídeo, fotografia, texto escrito e áudio. É a história de um casal de adolescentes, ele morando no Brasil e ela nos Estados Unidos, que se conhecem numa sala de bate-papo da Internet e iniciam um romance. Cada lance desse namoro eletrônico utiliza um dos recursos do meio - e-mails, imagens digitais, conversas em tempo real e teleconferência. Cada capítulo se encerra pela relação interrompida pela impossibilidade da comunicação - a ligação rompe-se, outras pessoas desejam ocupar o computador ou um dos jovens precisa sair para compromissos inadiáveis. Além do uso da linguagem multimidiática, esses ganchos tecem uma crítica velada aos limites da comunicação nos meios digitais. O próprio título da novela, $A t$ first site, reflete essa preocupação com um jogo de palavras.

Um exemplo interessante é apresentado no site Superbad (http:// www.superbad.com/1/trunk/trunk.html) onde o visitante encontra um labirinto de textos, aparentemente sem sentido, utilizando diferentes linguagens - textos escritos, cartoons, fotos e animações. $\mathrm{O}$ internauta percorre a esmo as diversas saídas, num percurso aleatório com o qual vai criando sua própria história. Um desses textos parodia uma história de aventuras - The mystery of Monster Mountain (and Captain America) que não só ironiza o gênero como os ganchos que encerram capítulos. Ao final de um texto cheio de non senses, o autor convida o leitor a nova busca entre páginas do site com a frase:

...to be continued... go to somewhere else.

No endereço http:// www.2.uol.corn.br/mixbrasil/

frasaiahtml há uma proposta de um conto interativo, cuja dinâmica parece inspirar-se em estruturas televisivas de programas do tipo Você Decide. Lição de Casa, escrito na primeira pessoa, relata a experiência de um professor que sofre assédio de um aluno homossexual. A história é interrompida quando o garoto finalmente o aborda, aparecendo na tela três finais possíveis para escolha do leitor:

O que deveria eu fazer agora?

a- Marcar o tal encontro e ver no que dava?

b-Esquecer aquilo e me livrar do garoto? c- Sentar com ele e esclarecer as coisas ali mesmo?

Depois da escolha, o leitor deve clicar numa barra de envio na qual está escrito: Agora está em suas mãos resolver esta situação.

Além desses exemplos que envolvem interatividade, multilinguagem e uma atitude crítica a respeito das formas narrativas consagradas por outras mídias, há experiências artísticas que brincam com essa atitude de permanente busca do internauta que parece ir de um lugar para outro de forma quase sempre inesperada, aleatória e cheia de surpresa.

$\begin{array}{ccc}\text { No endereço http./l } & \text { hw.chez.com/eu/perspcla.htm, } \\ \text { www. }\end{array}$

visitante encontra uma página que vai se desdobrando em inúmeras outras, com janelas e barras de rolagem que se abrem de forma aparentemente desordenada, sem que o usuário/leitor possa controlar o processo. Nessa brincadeira estética ele passa pela experiência de acessar sempre aquilo que não escolheu, mostrando a natureza infinita do meio e a dificuldade de seguir por um mesmo caminho. Nesse 
contexto, o gancho faz parte de uma nova gramática que se cria e se consagra. ${ }^{16}$

Os exemplos relatados mostram claramente que o gancho, enquanto recurso narrativo, pode se adaptar às mais diferentes tecnologias e que o sentido que resulta do processo comunicativo dependerá cada vez mais da capacidade de se construir um caminho viável entre textos cada vez mais fragmentados, abertos e aleatórios. Por outro lado, pudemos perceber que ao migrar de uma mídia à outra, o gancho altera sua função e sua inserção no processo produtivo das narrativas. Assim, na comunicação oral o gancho se apresentava como um recurso utilizado pelo autor ou narrador das histórias, sinal de domínio e conhecimento da linguagem utilizada e do processo comunicativo que conduzia. Nas mídias modernas que ensejaram a cultura massiva, vimos que o gancho se desloca - passa a ser engendrado pela equipe de produtores que com ele tenta disfarçar as interrupções técnicas e comerciais impostas pelo meio e pelo processo de produção industrial. Não se trata mais de um recurso oral e até artesanal, mas de uma tática e representa o domínio mais técnico do que estético da linguagem.

Nos meios digitais o gancho se insere definitivamente na gramática da informação, sendo o elemento de ligação entre fragmentos cada vez menores e menos consistentes. Sem o apoio da serialidade e sem a previsibilidade do final das histórias, os links vão se tornando cada vez mais evidentes, usando para isso recursos tecnológicos cada vez mais sofisticados - animação, sonoplastia, efeitos especiais. Não disfarçam os problemas do meio como a inacessibilidade de algumas informações, a demora no funcionamento de certos programas, a superficialidade de certos conteúdos, procuram, antes, minimizá-los, mostrando rapidamente a porta da saída ou rogando por tolerância através de uma ampulheta que indica o tempo de processamento. Sua inserção no processo produtivo também modificou-se: não se trata mais de uma tática utilizada por uma equipe de produção, mas de um mecanismo disponível no sistema. Com maior ou menor criatividade o gancho se tomou obrigatório nas narrativas digitais e mais do que obrigatório, tornou-se automatizado: ninguém o inventa, ele decorre de necessidades técnicas.

É possível que, com o tempo, as rotinas que o usuário venha a desenvolver através de seus computadores, assim como a integração próxima das diversas mídias com a necessária contaminação entre elas, tornem as narrativas digitais menos instáveis e fragmentadas. É possível que a relação entre pessoas distanciadas no tempo e no espaço venha a apresentar certa regularidade cotidiana e que certas vias se consolidem nesse mar cheio de navegadores que vão em todas as direções. Nesse caso é possível que o gancho recupere a proximidade subjetiva que o caracterizou desde as origens até sua consagração midiática.

\section{Conclusão}

Helena entra em casa, fecha a porta e corre os olhos pela sala de estar de sua casa, meio na penumbra. Sua expressão é preocupada. Começa a percorrer o cômodo em direção à porta que dá para a parte interna da casa. Passeia o olhar por tudo como se procurasse alguma coisa. Ela desconfia de que Edu, seu namorado, e sua filha Camila estejam se apaixonando um pelo outro. Ela vai para o seu quarto em busca de consolo, mas antes de se acomodar vê a porta fechada do quarto de Camila. Abre a porta e penetra no dormitório onde vê uma fotografia na qual aparecem sorridentes e despreocupados Camila, Edu e ela, num trágico triângulo amoroso pressentido pela máquina fotográfica. Sua expressão é amarga.

Nesse momento, aparecem na tela as seguintes opções:

1- Assista ao final traçado pelo autor.

2- Escolha um dos finais possíveis e assista à cena de sua opção:

a- Edu fica com Helena e Camila morre de leucemia.

b- Edu fica com Camila e Helena viaja para longe.
(16) Os sites aqui apresentados fazem parte da pesquisa As Formas Narrativas em Mídias Eletrônicas. Análise estética e sociológica - financiada pela FAPESP através de processo de número 99/01123-0. 
c- Edu viaja para longe, Camila morre e Helena casa-se com outro.

Não se esqueça de confirmar sua escolha clicando em ENVIAR.

3- Imagine um final seu para a história escrevendo no espaço abaixo e clicando em ENVIAR. Nossos editores lerão a proposta e selecionarão uma das contribuições para ser publicada no site. 4- Participe do game, contracenando com os personagens e interferindo no desenrolar da história.
5- Participe de um grupo de discussão a respeito de mães e filhas que se apaixonam pelo mesmo homem.

6- Links para outras histórias cheias de emoção.

Um sultão assombrado desiste de vingar-se das mulheres infiéis contra as quais impusera um castigo muito violento. Consola-se de suas decepções no mundo espetacular de histórias inconclusas.

\section{Bibliografia do artigo}

ALCÁZAR, Migdalia Pineda. Los processos de la comunicación a la luz de los medios interativos: revisiones conceptuales y de tipologias. Trabalho apresentado no V Congreso de la Asociación Latinoamericana de Investigadores de la Comunicación. Santiago do Chile, abril de 2000.

ARATA, Luis O. Reflections about Interactivity. luis.arata@quinnipiac.edu.

BACHELARD, Gaston - A poética do espaço - São Paulo, Martins Fontes, 1988.

CHARTIER, Roger. A aventura do livro: do leitor ao navegador. São Paulo, UNESP, 1998.

DEBORD, Guy - A sociedade do espetáculo - Lisboa, Edições Afrodite 1972.

ECO, Umberto. A obra aberta. São Paulo, Perspectiva, 1991.

Seis passeios pelos bosques da ficção. São Paulo, Cia das Letras, 1994.

FANUCCHI, Mario - A próxima atração - São Paulo, EDUSP, 1996

GUIMARÃES, Luciano. Autoria e Interatividade. http://www.geocites.com/Athens/ 1902/interativo.html

HUNT, Russel A.- Speech Genres, Writing Genres, School Genres e Computer Genres. http://www.stthomasu.ca/ hunt/smusite/

MACHADO, Arlindo - A Televisão levada a sério - São Paulo, SENAC, 2000.

MANGUEL, Alberto. Uma história da leitura. São Paulo, Cia das Letras, 1997.

MARCONDES FILHO, Ciro. Alice no país do videodrome: de como os receptores foram tragados pela interatividade da comunicação eletrônica. In: Revista Novos Olhares. São Paulo, CTR/ECA/USP, ano 2, número 4, ago/dez 1999.

MARTÍN-BARBERO, Jesús - De los medios a las mediaciones - Barcelona, Editorial Gustavo Gili, 1987.

MATUCK, Carlos - Hitchcock - Truffaut - Entrevistas - São Paulo, Brasiliense, 1986.

MEYER, Marlyse - Folhetim - São Paulo Cia das Letras, 1996, p.63 
MURRAY, Janet H. Hamlet on the Holodeck. the future of narrative in Cyberspace. New York, The Free Press, 1997.

OFFMAN, Craig. Admirável e-livro novo. In: Folha de São Paulo, Caderno Mais. São Paulo, 9 de abril de 2000.

OLIVEIRA, Ana Claudia e FECHINE, Yvana. Imagens Técnicas. São Paulo, Hacker Editores, 1998.

PALACIOS, Marcos. Hipertexto, fechamento e o uso do conceito de não-linearidade discursiva, http://www.facom.ufba.br/pesq/cyber/palacios/hipertexto.html

RICOEUR, Paul. Historia y narratividad. Barcelona, Ed. Paidós, 1999.

SILVA, Marco. O que é interatividade. Publicado no endereço http://www.senacnacional.br/boletim/boltec38.thm

VICENTE, Carlos Fadon - Tele-presença-ausência - Publicado no site da UNICAMP

WAGMISTER, Fabian. El arte digital es una obra abierta. Publicado em http:// www.clarim.com/suplementos/cultura/99-12-03/e-01210d.htm

WINKING, Yves. A nova Comunicação. Campinas (SP), Papirus, 1999.

\section{Bibliografia do autor}

COSTA, Maria Cristina. A milésima segunda noite - da narrativa mítica à telenovela. São Paulo, Annablume, 2000.

O gancho da telenovela - análise estética e sociológica. Relatório Cientí-

fico Final apresentado à FAPESP. São Paulo, junho de 1999.

As formas narrativas em mídias eletrônicas - Relatório Científico apresentado à FAPESP. São Paulo, maio de 2000. 